\title{
CONSIDERATIONS CONCERNING THE NECESSITY OF EXISTENCE A MODERN MILITARY INFORMATION SYSTEM IN THE CURRENT GEOPOLITICAL AND GEOSTRATEGIC CONTEXT
}

\author{
Sorin PÎNZARIU \\ "Nicolae Bălcescu" Land Forces Academy, Sibiu, Romania \\ sorinpinz@yahoo.com
}

Ana-Maria DIACONU

"Carol I" National Defence University, Bucharest, Romania anna_mariadiaconu@yahoo.com

\begin{abstract}
The latest military actions carried out at global level have highlighted, besides the number, the quality and diversity of the participants in the multinational operations and the differences, not at all negligible, regarding the capabilities of these actors to participate in military actions characterized by a high technical level and technologically, but not only. One of the areas that generated a real lack of standardization, with obvious impact on the operational compatibility of the various participants was that of communications and informatics and, implicitly, of the insurmountable differences between different information subsystems as parts of the information systems of the multinational operations. From this perspective, it became evident that the performance of each participant in the military actions of a multinational character was and we consider that it will be permanently conferred by their technical ability to cope with the information avalanche and to integrate into the information system of the mission.
\end{abstract}

KEYWORDS: multinational operations, technological level, standardization, interoperability, compatibility, information system

\section{Introduction}

The realities of the world around us, undoubtedly, show that the geopolitical and geostrategic environment created and established after the fall of communism in the 1990s, respectively after the end of the Cold War is in a process of profound transformation and is about to return there where we left, that is to say a new Cold War, in which situation, many specialists in geopolitics and geostrategic had rushed to declare the end.
From this perspective, we are witnessing today at a global level, a new arms race involving many states around the world, various political-military alliances and sometimes even non-state actors with different forms of organization.

It reached a technological level, without precedent, a number of states, trying to obtain more sophisticated military equipment and equipment, both defensive and offensive in the desire to protect or, in some cases, to protect themselves imposes national interests globally. 
The binder of all these actions carried out in different parts of the planet, seems to be the informational support generated by both the increasing level of training of the personnel and the increasing technical capabilities of all the categories of equipment used by the great actors of the world stage.

The accelerated pace of technological development, closely followed by a real explosion of risks and threats to both national and regional, regional and global security, has succeeded in creating a new situation at geopolitical and geostrategic level considered as a true map of military information system.

The model of the military information system is by far not the panacea sought for the architectural demands imposed by the current world geopolitical and geostrategic context, but it facilitates the approach of the technological progress in a modern way, with the risks and threats asymmetrical existing and possible future.

We believe that a well-defined and effective military information system will be a real "aid" in the efforts of the international community to fight coherently and effectively against present and future risks and vulnerabilities, from which military decision-makers will certainly draw their own conclusions.

\section{The Need for a Military Information System}

At the moment, we are witnessing a true "informational assault" that affects both states, as first-hand actors of the global geopolitical and geostrategic scene, international, non-governmental organizations and even the individual who no longer understands what steps to take to follow them in the relationship between needdesire-necessity.

One of the most famous visionaries, Winston Churchill appreciated this scenario, predicting that: "... the empires of the future will be empires of the mind" (Manci, Magaliuc \& Preja, 2014, p. 19).
Interpreting the words of the great politician we can say that information is a real foundation in the process of knowledge, and whoever holds the information has practically absolute power.

Information, the most valuable resource of "power" is long and thoroughly analyzed in all its aspects and forms, highlighting itself as a relevant and obvious reality that leads to the present concerns regarding the modernization of the information system.

Not only from a personal perspective, but also from a technical and technological point of view, we believe that information is a real exchange currency and, at the same time, raw material for both global geopolitical players and the most important power centers around the globe.

By reporting to the information system, we perceive a set of elements that are designed to collect, process and transmit information, which is a central role in the entire flow and information circuit. Various specialists in the field define the information system as " ... all data, information, circuits and information flows, procedures and means of handling information intended to contribute to the substantiation, establishment and realization of the organization's objectives system" (Burduș \& Căprărescu, 1999, p. 162).

From the point of view of the beneficiary of such a system, I consider that the existence of a military information system confers and facilitates the good gait of the military organization, notably by:

- obtaining a common operational picture/COP of the conflict zone;

- to trim connections between supply chain sources;

- enhancing information security at national level;

- real-time identification of stocks of existing materials;

- the allocation and judicious planning of the resources provided in accordance with existing stocks in the database;

- increasing the performance of the military organization; 
- diminishing national security vulnerabilities using existing information capabilities and those in the endowment of NATO and EU member States.

Between the various terms used in the field of communications and information we retrieve synonyms such as information circuit, informational flow, informational superiority or informational supremacy, to remember the most common of them.

When we refer to the highest form of domination, in the field addressed, that is to say, information superiority, we must mention that for a state wishing to achieve this level (absolute superiority quantized with power and authority) must be have the capacity to be superior, both geopolitical and geographical, and by equipping with state-of-the-art technique and equipment and to reach out to information the other States (by the power to influence those around, or by number, or intensity).

We believe that all these elements can represent a rich operational and strategic advantage for the state in question.

In order to deepen the importance of the need for a well-outlined national information system, we consider that we could exemplify the way in which the events of the invasion of the Russian Federation of Georgia were to be conducted. Thus, cyberattacks were initially executed on official websites of Georgian public institutions (that of the Presidency, Government, Foreign Ministry and Ministry of Defense). Due to the fact that most communications and computer networks have not been operational for a long time, the Georgian authorities have not had the capacity to inform the international community and its own citizens about the actions carried out by the Russian Federation, on national territory.

At the same time, the main news sites in Georgia and a large part of Georgian online forums have become inaccessible. Another effect of the informational warfare was blocking the electronic transactions of the main banking institutions, which generated a real chaos among the entire population, exposed to the informational attack, without understanding what was happening.

When we refer to the highest form of domination, in the area addressed, that is to the information superiority, we must mention that for a state that wants to achieve this level (absolute superiority quantified with power and authority) it must have the capacity to be superior, both by geographic, geopolitical position, as well as by endowment with state-of-the-art equipment and equipment and to become informationally dominated by the other states (by the power to influence those around, either by number, or intensity).

We consider that all these elements can represent a rich operational and strategic advantage for the state concerned.

In order to deepen the importance of the necessity of a well-defined national information system, we consider that we could exemplify the way of the events leading up to the invasion of the Russian Federation of Georgia. Thus, initially cyber-attacks were carried out on the official sites of the Georgian public institutions (the one of the Presidency, the Government, the Foreign Ministry and the Ministry of Defense). Due to the fact that most communications and IT networks have not been operational for a long time, the Georgian authorities have not been able to inform the international community and its citizens about the military actions carried out by the Russian Federation, on the national territory.

At the same time, the main news sites in Georgia and much of the Georgian online forums have become inaccessible. Another effect of the information war was the blocking of the electronic transactions of the main banking institutions, which generated a real chaos among the entire population, exposed to the information attack, without understanding what was happening.

In this context, the Tbilisi authorities made the decision to seek the help of the international community in order to combat 
cyber-attacks by the Russian Federation on their own institutions. Thus, to combat this phenomenon, Estonia (which in 2007 had a similar experience) came to Georgia's help with specialized cyber security personnel, with the mission to mitigate the effects created by cyber-attacks. Such an action is being carried out, at the moment Romania, helping the neighboring country, Ukraine, which has been subjected for a long time to cyber-attacks by the same Russian Federation.

In view of the presented ones, we believe that the purpose for which the information system must be developed and anchored at the technical and technological leap on the level of the international environment, is to know thoroughly the status and position of the national military situation, the degree of endowment with forces, means and equipment as well as the way information flows within the internal system of the military organization.

By virtue of what is happening at the planetary level, the military information system can be compared to the "army", which has several categories of "soldiers" that have the role of helping to identify, in a timely manner, the possible risks and threats to the national military system. The anchoring of the national military information system in the current geopolitical and geostrategic environment leads to the identification and prevention of possible events of an asymmetrical nature and can help to ensure a prompt and efficient reaction in a situation similar to the one presented.

\section{The Modern Military Information System in the Current Security Environment}

The need for a modern military information system is undeniably highlighted by the latest global military events, including conflicts in Afghanistan, Iraq, Georgia, North Africa, the former Yugoslav space and cyber-attacks in various areas of the globe.

A modern information system allocated to the military system should provide, in our opinion, all the information necessary for decision-makers in the complex effort of making decisions based on the accuracy, reality and timeliness of the information.

A modern military information system should have information subsystems specific to the functional areas of the armed struggle (operations, logistics, information, human resources, communications, etc.) that will be integrated into a unique concept of processing and distributing information to the decision makers military.

On the other hand, a military information system must be "fed" with information transmitted on all communication channels, including here the information transmitted by the sensor network installed on the military technique and equipment, the enemy information and its most important capabilities, the information obtained through the global network of satellites, those obtained by specialists in information structures, research, etc.

The arguments in favour of such a system lie in the necessity of shortening the decision-making time, namely from the devout of the enemy in carrying out the whole decision-making process. Another argument towards the existence of a military informational system is given by the fighting power of the structures benefiting from the information provided by such a modern capability which requires the allocation of substantial financial funds.

As is known, the large units and combatant units with an increased level of computerization and digitization have a concrete chance of gaining victory in the face of much more numerous structures, but do not also benefit from military capabilities.

\section{Conclusions}

Permanent technological renewal, doctrinal, organizational and actionary developments are also elements that contribute to changing the physionamia of military actions in the near and distant future. The spectacular developments in these areas are unequivocally giving rise to 
notable changes in the form of conduct and, in particular, the management of military operations. In equal measure, rapid access to information and a seamless military informational system will always enable the pace to be increased within the decisionmaking cycle at the level of the military organization.

From this point of view it is evident that the main features of the military information system consist of "Dependence of electronic networks and in handling, processing and exchange of information with speed lights" (Stoiu, 2010, p. 324).

In this respect, it appears as a necessity, first order, to implement a national military information system that would increase the quality of the flow and information circuit and, at the same time, to ensure the elimination of shortcomings in the collection process, synthesis, storage, processing and dissemination of data and information necessary for military decisionmakers.

In the same context, information flows will diminish the boundaries between international actors, trends towards regionalization and globalization will return, and the beach of security risks and threats will widen. Thus, the main vector for an informational potential becomes, without just being possible, the continuous updating of the military information system in line with the trends of the current geostrategic and geopolitical context.

By understanding the risks to which they have been exposed, the states that have experienced cyber-attacks will be able to understand the current and future nature of a conflict/war, having in mind, always, that future challenges can surprise us and change our perception of conflict/war.

\section{REFERENCES}

Burduș, E., \& Căprărescu, Ghe. (1999). Fundamentele managementului organizației. București: Editura Economic.

Manci, I., Magaliuc, D., \& Preja, C. (2014). Managementul informațiilor militare în actul decisional. Sibiu: Editura Academiei Forțelor Terestre "Nicolae Bălcescu".

Romania the Presidential Administration. (2015). National Defense Strategy 2015-2019: a Strong Romania within Europe and the World. Bucharest, available at: https://www.presidency.ro/files/userfiles/National_Defense_Strategy_2015__2019.pdf, accessed on 07 September 2019.

Stoiu, Ghe. (2010). Dimensiunea informațională a spațiului de luptă modern. Buletinul Universității Naționale de Apărare "Carol I", Nr. 2, 324-331. 